Flockemann, M. (2010). Little perpetrators, witness-bearers and the young and the brave: towards a post-transitional aesthetics. English Studies in Africa, 53(1): 21-34

\title{
Little perpetrators, witness-bearers and the young and the brave: towards a post-transitional aesthetics
}

\section{Miki Flockemann}

'We have to explore ways of telling stories that are different from the ways we are used to' -Mpumelelo Paul Grootboom (Jones)

The aesthetic choices characterizing work produced during the transition to democracy have been well documented. ${ }^{1}$ We are currently well into the second decade after the 1994 election - what then of the period referred to as the 'second transition'? ${ }^{2}$ Have trends consolidated, hardened, shifted, or have new 'posttransitional' trends emerged? What can be expected of the future 'born free' generation of writers and readers, since terms such as restlessness, dissonance and disjuncture are frequently used to describe the experience of constitutional democracy as it co-exists with the emerging new apartheid of poverty? Furthermore, what value is there in identifying post-transitional aesthetic trends?

A work like Relativity: "Township Stories" (2006), co-authored by controversial director Mpumelelo Paul Grootboom (winner of the 2005 Young Artist Award for theatre) and Presley Chweneyagae (of Tsotsi fame), offers a useful point of departure for identifying some of the post-transitional aesthetic trends that will be the focus of this discussion. For example, there is a scene where a township drunk declares passionately, 'Oedipus? I have suffered more than Oedipus!' ${ }^{3}$ Such darkly comic moments in this brutal film noir-styled expose of a serial killer's rampage manifest, as I will argue, a post-transitional aesthetic in the bravado of the play's self-reflexive intertextuality. This ranges from TV drama, pop psychology, Shakespeare and the classics to Hollywood crime genres. However, it extends beyond 'a tissue of quotations ' (Barthes 146) to generate both the disruptive and productive effects of offering an unanticipated or 'contra-standard' aesthetic effect ${ }^{4}$ that challenges spectator expectations. Moreover, the reference to Oedipus is not simply gratuitous, as the man who sets out to find the so-called 'G-string strangler' plaguing the community discovers he has literally and figuratively engendered the killer himself. This concern with the 'little perpetrator ' or the 'perpetrator within' (Sanders) is another prevailing trend that can be associated with post-transitional aesthetics.

Grootboom admits that his aesthetic choices are informed by an attempt to try to understand violence (Corrigall 'Iconoclast'), and this points to what has been described as 'witness-bearing' writing as opposed to 'eye-witness accounts'. According to Kelly 
Oliver, the latter deals with historical facts, while 'witness-bearing' refers to the structure of subjectivity itself as it entails bearing witness to a truth about humanity it presents 'phenomenological or psychological truth' (80), even if imagined. The violence that is so graphically witnessed in the play becomes Grootboom's attempt to explore his own traumatic past, but also aims to provoke response to the experience of living in what seems to be a morally chaotic South African present. These three broadly described and often interwoven trends associated with a post-transitional aesthetic, namely, the focus on the little perpetrator, witness-bearing and intertextual play, are of course not new developments. Before looking more loosely at how these trends are articulated in some recent works, one needs to take account of the genesis of such literary tropes during the last few decades.

Needless to say, attempting to outline post-transitional aesthetics inevitably involves some slippage between aesthetic choices simply common to a particular historical period, and identifying how these reveal ideological and cultural shifts. After all, aesthetic trends are situated along a continuum that includes working within, and upon, familiar forms as well as more experimental ventures informed by a futuredirected sense of urgency. What follows is not an attempt to provide a comprehensive overview of current trends -post-transitional or not; instead, the aim is to offer an open-ended response to trends that have appeared to dominate during the past five years. In looking at some of the general directions that can be tracked in recent works, the focus will be on those aesthetic choices imbricated in modes or structures of address and intertextual play. The examples used to illustrate features of a posttransitional aesthetic are drawn from established writers as well as work produced by a younger generation. For instance, Thando Mgqolozana 's debut novel, A Man Who Is Not A Man (2009) will introduce discussion of structures of address that explore the nexus of complicities which Mgqolozano's text bears witness to. On the other hand, Playing in the Light (2006) by Zoe Wicomb will serve as an example of a text that slides along the transitional and post-transitional continuum. Finally, I return to Relativity: "Township Stories" by Mpumulelo Paul Grootboom and Presley Chweneyagae in the context of work that illustrates a post-transitional aesthetic from the perspective of the new generation of urban youth. By way of comparison I will also touch on other works by new writers like Kopano Matlwa's Coconut (2007), Asanda Phewa's A Face Like Mine (2009), and Niq Mhlongo's Dog Eat Dog (2004).

As suggested above, the illustrations of post-transitional aesthetics identified in works by Mgqolozana, Wicomb and Grootboom are part of a continuum of by now familiar trends emerging during the period of the first transition. These range from writerly texts presenting an often anxious and traumatic transitional aesthetics to articulate the previously unsayable, to works employing a reconciliatory, and even exuberantly transformative or 'utopian aesthetics', which offer an imagined reconciliation of 'what is currently fragmented or divided' (Eagleton 9). At the same time, the use value of 'grounded aesthetics', which allow individuals to make cultural sense of the everyday world, also needs to be taken into account, particularly in more popular forms (see Willis, Gilroy). ${ }^{5}$ More recent assessments by local commentators often employ suggestive metaphors to describe trends (see de Kock et al.). ${ }^{6}$ These include the provisional hitching or stitching together of differences and sameness, in the process 
unravelling familiar binaries, and discovering entanglements, emerging cosmopolitanisms, productive transnational encounters and the intimacies of human foldedness and complicities, as well as the complexities of attempts to accommodate the stranger, and the strange.

One of the most prevalent trends - predictably, given our history - is the concern with diversely articulated manifestations of complicity with social injustice and prejudice, whether direct, covert, or by proxy. As mentioned earlier, this commonly concerns the little perpetrator within, in contrast to the more starkly visible perpetrators of the apartheid state. While this has been an abiding concern for established writers like Coetzee, Gordimer, Wicomb, Mda, Vladislavic, Brink and Ndebele, among others, it also features strongly in works by a younger generation. Linked to this is a shift, noticeable across genres, from, as Oliver puts it, 'What They Did to Them/Us', to 'What Did We Do', or more recently (in keeping with some post- transitional trends), 'What Are We Doing to Ourselves ', which often also entails an acknowledgement of the perpetrator within. Another facet of this trend is the ongoing negotiation between given and emerging identities, including a focus on ambivalence (such as the preoccupation with the figure of 'the coconut') and a questioning of both blackness and whiteness to excavate an 'unknowable racial subject' (Nuttall 94). It is hardly surprising then that one of the most notable features of work produced since the transition to democracy is an inward turn. Finally, there is the emergence of fresh young (primarily urban) voices producing often intertextually hybrid works that speak boldly about 'being' in South Africa in the here and now, usually from the perspective of youth.

In gauging how aesthetic choices reveal ideological and cultural shifts, I return to the question about the value of this concern with post-transitional aesthetics. Ifone accepts that the aesthetic properties of a work are not separable from its nonaesthetic properties, its history, or from the commonly accepted Gestalt of the category in which the work is perceived, ${ }^{7}$ it follows that exploring post-transitional aesthetics is useful for examining the way in which prevailing ethical and social landscapes are translated into text. It is claimed that the narrative arts (including fiction and drama, the examples used here), lend themselves readily to this, not for what they 'tell' us, but for 'what they bring home to us' through the deployment of 'an affective mode of cognition' (Anderson \& Dean 160). As Carroll says, 'It is of the nature of narrative to be incomplete' (277) and the 'filling in' undertaken by the reader becomes a way of rehearsing moral and ethical judgments: 'it is natural for us to discuss narrative artworks by means of ethical vocabularies' (277). However, like Anderson and Dean, he stresses that the artwork does not 'teach' new moral tenets; rather, it involves being able to see connections between abstract moral precepts and concrete situations (Carroll 229-230). Part of the value of identifying a post- transitional aesthetics then, is the light that this might throw on the prevalent preoccupation with ethical considerations, and the attendant problematics and disjunctures that are foregrounded in imaginative literature.

By stressing the functions of modes or 'structures of address', I am drawing on the claim that the literary has the potential for providing structures (even if imagined) in which one can address others, and be addressed by them, and in tum achieve 
'response-ability (the ability to respond to others and oneself)' (Oliver 83 ). ${ }^{8}$ The selfreflexive 'writerly' preoccupation with structures of address is also evident in the way writers themselves reflect on the range of possibilities informing aesthetic choices. For instance, writer-director Grootboom sees his plays as an attempt to produce 'more original' and 'more experimental' work, claiming that, 'we have to explore ways of telling stories that are different from the ways we are used to' (Jones). This implies not just that the stories must be told differently, but also that the audience should be open to what they are 'unused to'; they must be willing to have their familiar response categories unsettled. But who are 'we', and what kinds of storytelling are being referring to - traditional, literary, or popular? Both Grootboom and Chweneyagae are self-proclaimed film fanatics and have been involved in the film and TV industry; this suggests that they work within a broad- ranging globalized intertextual/media framework. On the other hand, some writers have been using a variety of platforms (including the internet) to raise issues from within the local literary community. Award-winning debut novelist Russell Brownlee, for instance, calls for writing that shifts from thinking in categories to embrace complex narrative forms using powerful language to articulate 'life lived in details' in order to create a larger world. His own writing aims to be typically writerly in its focus on expressing the 'unnameable' ('It's that sense we all have of being indefinable'), and Brownlee claims he is looking for new novels in South Africa that 'relinquish control', since 'we have lost the art of living in paradox and uncertainty.$^{9}$ Commenting on the need for developing a critical language receptive to emerging literary trends, Sarah Nuttall (among others) urges that analytical tools need to be found that will produce 'a greater receptivity to new literary formations' (94). ${ }^{10}$ This 'receptivity' suggests the need for open-endedness and informs the comparative or relational reading of texts as diverse as Mgqolozana's attempt to 'be a voice for the voiceless' (Isaacson) in exposing the culturally taboo subject of male circumcision, Wicomb's elegant writerly exploration of whiteness, ('What is this chimerical thing that they strive after?'(151)), and Grootboom and Chweneyagae's abrasive and confrontational expose of the relativity of contemporary urban morality.

The startling cover image of a young Xhosa initiate's face split off in shards at one side captures the tension between eye-witness accounts and 'witness-bearing' that underpins Thando Mgqolozana's A Man Who Is Not A Man. At the same time, this points to what can be described as a post-TRC turn in exploring the ethics of traditional cultural practices from within. Mgqolozana's novel has provoked controversy for exposing what are seen as culturally sacred ritual secrets in presenting a closely observed insider account of a botched circumcision - botched in this case because of the failure of care traditionally expected from those attending to the initiate (here, unforgivably, the failure of his grandfather and uncle). Mgqolozana claims that he is not opposed to the traditional Xhosa practice of male circumcision per se; he is more concerned with human rights (especially children's rights) that are often violated in the process. Mgqolozana's epigraph from Doctorow ('There's no longer any such thing as fiction and non-fiction, there's only narrative ') points to the dialectic established between the author's own similar experience, which was the story that 'chose him' in the process of writing (Isaacson), and the self-reflexivity of the narrative 
that as it were experiments with the fragmented voices and selves that eventually coalesce, if not heal, so that he is able to tell the story, that is not only his.

The novel is framed by a prologue and epilogue addressed to the reader to explore not just what happens to the initiates on the mountain, but more importantly, 'what do they become?'(2). Individual chapters are structured to mirror the splitting and coalescing cover image as segments of experience are narrated in apparent nonlinear loops, often using distinctive narrative discourses or modes of address to bear witness to what Oliver refers to as the structure of subjectivity that is the focus of Mgqolozana 's narrative. The prologue adopts an intimate tone in eliciting response (ability) by confiding that, 'Whoever you are and whatever you believe in, know that you are the first person I am telling this story to. I have kept it inside me for too many years, and I thought it was time I should relieve myself of the heavy burden' (4). Metaphors of health and cleanliness articulate the 'inner burden' of dealing with the consequences of a septic circumcision; it is claimed that some would see this as 'hanging out dirty washing', but for the narrator it is a way 'to begin to get to the source of the rot infecting our society' signified here by the septic penis (4). Describing his narrative as a 'coming clean' about taboo cultural rites of passage into manhood suggests personal culpability -even if coerced -while also pointing to the 'world's eye' that judges him.

This double vision introduces the shifting perspectives adopted in the chapters that follow, and brings to mind both Ellison's Invisible Man and Du Bois's famously coined experience of the 'double consciousness' of the black man who sees himself through the world's eye. Here, however, it is not the man's race but his culturally defined manhood as symbolized by his 'properly' circumcised penis that renders him visible as a 'Man' in the eyes of his community. At the same time, there are suggestive parallels to be drawn also between Mgqolozana's narrative and Toni Morrison 's The Bluest Eye, which also dared to explore a 'taboo' subject (incest) from within, for which Morrison received criticism from some quarters for telling 'our secret' to the wider world. In fact, it is interesting that references to. 'lifting the veil' and exposing intimate and embodied 'secrets', and 'breaking silences', which have commonly been associated with narratives of gendered female oppression, are evoked here to raise questions about what it means to be a Man. The shifting modes of address employed, like the commonly polyvocal narratives associated with work like Morrison's The Bluest Eye, here becomes a vehicle to expose the intimacies and anxieties of what manhood entails and how it might be strategically redefined in a post-transitional context. The broader significance of this fictional exposure is evident in the aftermath of the so-called xenophobic pogroms of 2008, which involved disaffected youth as instigators. Commentators (such as Hassim et al., Gobodo Madikezela and Ashton), identified the attacks as 'symptoms' of underlying social 'causes', including the sense of personal humiliation and rage experienced by impoverished or unemployed youth, which is exacerbated as a result of the absence of intimate and nurturing family relationships.

Mgqolozana's first chapter gives a harrowing but at times comic account of the narrator's admission to hospital with a septic penis after his fourth day of 
isolation following the circumcision. His acute sense of personal humiliation and cultural shame is communicated through an exaggerated focus on prolonged time and partially glimpsed medical personnel identified only by their speech and the pairs of shoes which dominate his limited (because crouched-over and wheelchair bound) line of vision. In the next chapter, however, his younger self's criminal escapades with two friends on the margins of society in Cape Town are narrated in the style associated with the bravado and uncompromising realism of the kwaitostyled writing of, say, Nie Mhlongo or Kgebetli Moele ('we cockroached out of the vicinity without being noticed ' (20)), in sharp contrast to the abject and inward-looking individual encountered in the first chapter. To save him from inevitable ruin in the city, he is sent back to the Eastern Cape village of his childhood, where he undergoes a series of personal 'conversions' (in an apparent reversion of the usual village/city paradigm), which contribute to his decision to undergo the traditional Xhosa rite of passage into manhood before entering the University in Johannesburg. However, his fluid subjectivity during this period becomes evident in the sense of physical dissociation and constant negotiation between his objectified 'head people' and his emotion-driven 'chest people', while his penis is a 'limb' that appears to have a life of its own.

In one of the novel's strongest scenes, the disillusioned and angry young initiate awaits the group of men coming to greet him as a 'failed' man following his visit to hospital. As he sits provocatively astride, rather than (as customary) inside his solitary mountain hut, he begins to realize that despite having fulfilled all his obligations as an initiate, it is in fact his very failure that the men of his community long to see. That they have brought their dogs with them appears to confirm this, and he empathizes with the fear of his own companion dog at their approach, which speaks volumes about his half-articulated sense of manhood and belonging at this moment: 'My dog gave me that look again; this time there was fear in his glassy eyes. He was scraping the dust, causing turmoil with his hind legs while he made heartbreaking moans. Urine dripped from his member. He was calling me to his defence' (147). He notes, however, that what his dog does not know is that his chest people are daring the dogs to approach his dog so he might 'teach them a lesson they wouldn't forget' (147). The combination of defiance and recognition of customary codes is skillfully negotiated as he both tests the men (by brutally damaging the prize dog that is apparently set on him, using his knobkerrie, symbol of the initiate's manhood), and is himself tested in the process of being rescued by two elders. These older men show him the kind of 'care' his own grandfather and uncle failed in. Their strategic intervention also points to the possibilities of resilience despite apparent cultural strictures. In fact, when another elder, who occupies a position of authority in the community, tells him that manhood is defined by strategy ('Ubudoda licebo, mfowam. A man is a man for his strategy'

(170)), this appears prophetic. At the end of the novel the narrator claims, 'Writing about what happened to me is the only way I can say what I have to say and put it behind me' (180), suggesting that the narrative itself is a strategy for claiming and defining 'manhood'. 
It is a pity, then, that the epilogue becomes rather laboured in returning to the style of the prologue but without the playful anticipation of the diversity of readers being addressed. Instead, the prologue adopts an at times quasi-reconciliatory tone, which seems slightly strained in pre-empting the reader from 'filling in' the narrative. This is possibly because of Mgqolozana's stated intention to focus on human rights violations rather than presenting a blanket critique of male circumcision (Isaacson 2009). At its best, however, it is the work's own self-reflexive (and for the purposes of this discussion, post-transitional) strategy of shifting modes of address which extends the discussion beyond what becomes of a 'failed' man to draw attention inward to a failure of care closer to home. It can be argued that Mqgolozana's novel embraces both a posttransitional and a transitional aesthetics in that it continues the trajectory of positing a type of renewed (and idealistic) humanism that, as Ronit Frenkel points out, is associated by the works of earlier writers such as the late Phaswane Mpe and K. Sello Duiker.

Another example of a text that can be read as demonstrating both transitional and post- transitional aesthetics is Wicomb's Playing in the Light. The narrative is focalized through Marion Campbell, and explores her coming to consciousness of her own complicity in the 'pretence' of her parents, who passed as white in order to provide their only child with privileges that had been denied them. This privilege inflicts psychic damage on the whole family, requiring strict vigilance to maintain the pretence, and results in self-imposed exile within the white community, and obsessive separation from the coloured communities in which they had grown up.

This narrative, which bears witness to family secrets and the psychic trauma of negotiating racialized identities, expresses itself through the unconscious via the recurring nightmares experienced by Marion in the comfortable muslin-draped bed in her Atlantic seaboard apartment (31). The novel explicates Marion's memory of her mother's preoccupation with policing the body as part of constructing a strictly not non-white identity. Wicomb's deft incorporation of the oral quality of heard speech into the narrative works effectively to reveal layered, sometimes contradictory, stories and realities. ${ }^{11}$ An example of this technique (which Wicomb employs throughout her oeuvre), is Marion's perception of her father's reaction to an offer of help for his neglected garden: 'But he'll have none of it. They kill you in your own garden, hack your head off with your own blunt spade. Haven't you seen the papers' (13). The absence of quotation marks contributes to the excavation of layers of life-denying prejudice that are now made visible to Marion in hindsight, unsettling her quasicomfortable situation in the post-apartheid present. But this also introduces her to a potential other self-mirrored in the heard speech of her employee-companion, Brenda, who inhabits, assertively, the community that Marion's parents had worked so hard to distance themselves from. In pursuing these concerns, the work covers a by now familiar literary terrain, self-reflexively speaking to texts by Sarah Gertrude Millin, Coetzee, Gordimer, and of course Toni Morrison. ${ }^{12}$ However, at the end of the novel there is a shift which suggests a post-transitional turn within the text. This occurs when, during a trip to the UK and Scotland, Marion experiences an epiphany of sorts triggered by what could be described as an open-minded experience of 'light', as light 
itself, rather than as a concept which up to that point seemed always tainted by raceinflected complicity and pretence.

As she leaves a restaurant in Glasgow after a bout of rain, Marion feels 'decanted into another world', and notes: 'It is late, eleven o'clock, but the northern light lingers; the night sky is still flushed with the memory of sun, and the blonde sandstone buildings hum with an eerie pellucidity, as if it is there, from the denseness of stone, that stored light is being released' (200). This is an emancipatory moment in that light is 'unfixed' from its stranglehold of association with repression and the death of desire. Instead, in this 'un-used to' situation away from home (and this 'un-homing ' is crucial to her altered perception) she is able to revision light as 'released' from stone. At another level of textuality, however, it is Marion who is (albeit only briefly) released, even if she does not fully recognize this. Referring to an earlier description of her attic room in London with its 'deceptive light' filtering into the room that 'lures her into memory' (196), Johan Jacobs comments astutely on Wicomb's metafictional reflection on racial and cultural identity in describing Marion's response to suddenly 'seeing' a rectangle of sunlight projected onto a wall which appears to have a life of its own: 'The rectangle is a painting, or rather a painting in action, of white light on a white wall' (192). According to Jacobs this represents a shift in her understanding of identity in that the play of light on the static white wall, 'with its forming and re-forming abstract images', signals 'the increasingly complex, unpredictable and irreversible course that Marion 's life has taken since her discovery of her coloured parents ' decision to recreate themselves in terms of whiteness' (6). However, he notes that Wicomb's novel does not leave Marion with a greater understanding of herself, but rather that the 'cultural repositioning of herself is an ongoing process, and one which is necessarily inconclusive' (9). Nevertheless, such interventions point towards a posttransitional aesthetic by acknowledging the inconclusive re-positionings of identity, while simultaneously, through these lyrical intercessions, suggesting the imagined glimpses of post-racialized senses of self as suggested by the contradictory and multivalent uses of 'light' and 'play', that is not always pretence. ${ }^{13}$ This epiphany occurs as a result of Marion's own 'contra-standard' aesthetic experience of light, here disassociated from the category of 'whiteness'.

It is useful to compare Wicomb' s writerly explorations of identity with other recent more reader-orientated texts on being young, black and female in South Africa such as Kopana Matlwa's Coconut (2007), since the figure of the 'coconut' is commonly used 'to express or depart from a mode of racial being' (Nuttall 94). According to Lynda Spencer, while critical attention has been paid to established black women writers like Head, Wicomb, Ngcobo, Tlali, Kuzwayo and Magona, there is insufficient attention to a new generation of 'born free' writers. ${ }^{15}$ Matlwa's novel explores the situation of 'coconut' as a 'painful tragedy' (Spencer 77). However, while the experience of being labelled 'a coconut' can undoubtedly result in feeling continually compromised, 'suspended between two worlds, belonging nowhere' (77), there are examples of texts which employ structures of address to the experience of the 'coconut' more complexly and open-endedly (such as Fred Khumalo 's Seven Steps to Heaven). ${ }^{16}$ These point to a post-transitional aesthetic absent from Matlwa's text, caught up as it is in the 'tragedy' of the coconut. This might suggest that writerly explorations of identity lend themselves 
more readily to identifying post-transitional trends; however, one should avoid generalizations as the post-transitional aesthetic is not necessarily coupled to this.

The preoccupation with a 'knowable racial self' has become a prominent feature of a new generation of voices, particularly in recent performance genres where the use of physical theatre and visual spectacle offer rich scope for de- and re-constructing racialized selves. In her play A Face Like Mine, Asanda Phewa tackles similar tensions between worlds as described in Matlwa's Coconut, but using a much more confrontational aesthetic: this has her literally and figuratively strip off layers of designated selves in a ritualized redefining of contempory 'blackness'. This, she says, is a 'scary' venture because it involves charting new territory that many fear. ${ }^{17}$ At the end of her play, Phewa puts on a maid's uniform to indicate the dangers facing those like herself who attempt to challenge concepts of what blackness or whiteness is: 'if yo deny us roo to grow, we fall back on fhat we know' (Corrigall 'Black Hope' 26). This strikes a chord with Grootboom's comments on the need to tell stories 'differently'. Phewa's A Face Like Mine tackles risk headlong: after all, stripping herself naked in front of an audience can be read 'in the way we are used to'; we can become voyeurs of her objectified body (which might be why the play had an age restriction during its run at the 2009 Grahamstown Festival). Nevertheless, this does not prevent less 'open-minded' spectators from questioning what they see as Phewa's gratuitous 'antics' (Corrigall 'Black Hope' 26). Works like Phewa's embrace contradictions, and are brave - yet also both tender and angry. A significant aspect of the post- transitional aesthetic in A Face Like Mine is Phewa's use of theatrical spectacle: she makes a spectacle of herself to challenge received notions of blackness, but also as a form of dissent that usurps or reclaims agency over one's own representation. As Loren Kruger points out, when women make public spectacles of themselves in performance (instead of being 'made a spectacle of') they own the production of their own spectacle (Goodman 236).

Another feature characterizing new urban-based voices that have emerged recently, which usurp familiar representational modes in order to claim a local situatedness that both resists and tries to accommodate the burden of history, is the unapologetic claim, 'we are here now; you better get used to it'. This is evident, for example, in the novels by Niq Mhlongo and the plays by Grootboom. Mhlongo continues the tradition of writers like Phaswane Mpe and K. Sello Duiker, but uses a less complex structure of address than we see in Mpe and Duiker, or for that matter, in Grootboom. Both Grootboom and Mhlongo draw on local and international popular culture, including music, film as well as literature and theatre. Mhlongo, in the style of the readerly text, writes from a position of urgency, of having something to say, 'to help readers to dream about the things that are missing in their lives' (Arenschield). Through Dingz in Dog Eat Dog (2004), says Mhlongo, 'I wanted people to be able to understand the complex nature of the kwaito generation' (Meyering), and the novel can be seen as an example of what Ndumiso Ngcobo heralds as 'the kwaibook' (Nuttall 95). Like kwaito music, which draws on a variety of influences, musical and linguistic, Mhlongo 's text reworks cultural models to address a generation of young South Africans, and he has been compared to Can Themba, Mthuthuzeli Matshoba and Spike Lee (as has Grootboom). 
At the same time, it is significant that despite the system of localized linguistic and cultural reference, Dog Eat Dog speaks to readers in the wider world as well. For instance, it has been translated into Italian and won the 2006 Spanish Mar de Letras (Isaacson 2008). In a piece titled 'Bubo on My Groin', Uche Peter Umez claims that 'unless you lance the Bubo [boil] you cannot walk easily'; similarly, Mhlongo's text ruptures a festering malignancy. Umez notes how, in juxtaposing Mhlongo's texts with his own Nigerian-located reality, 'I realize, quite ironically, that a chillingly similar fate is shared by the majority of the citizenry of both countries: a fate that pounds the impoverished millions' (Umez, 2008). Inkeeping with Grootboom 's work, there is a concern with the 'relativity' of values, which Grootboom as director develops through intertextual play and genre slippages where techniques of film such as the flashforward, flashback, and rewind are incorporated in staging devices as the actors literally run backwards to 're-play' the serial killer's attacks. It could be argued that in his harsh expose of the relativity of values, Grootboom (like Mhlongo) occupies a type of middle ground. In other words, Grootboom and Mhlongo's work seems to mediate between, on the one hand, a cynical future-directed self-interest as evinced in the works of some contemporaries (like Kgebetli Moele's Room 207) where, as Ronit Frenkel points out, 'History, it seems, is no longer of interest' (5), and, on the other, 'the idealist drive found in earlier texts like Mpe's rooted in cosmopolitan humanism '(Frenkel 11).

Grootboom (dubbed the Township Tarantino - a term Grootboom rejects, just as he rejects the category 'township theatre ') claims that he is in the business of exploring limits. In keeping with what Willis (1990) refers to as a grounded aesthetics, which are employed to make cultural sense of the world, Grootboom says, 'Iwrite about my own experiences and I try to make them artistic' (De Vries). One of his primary concerns is the cyclical nature of violence, its motivations and effects (De Vries). One could say that Grootboom uses the crime thriller as framework for flushing out the metaphoric 'bubo' in the groin of the community he has lived in, using a jarring musical counterpoint to foreground a landscape of dissonances and in the process presenting a chilling take on the shift in ethical considerations from 'What Are We Doing to Ourselves', to include underlying causes of the 'How and Why'. This is a world without redemption, though shot through with glimmerings of tenderness. Drawing on references from the classics to Catcher in the Rye, the play invites comparisons with Dostoevsky's Crime and Punishment and Francis Ford Coppolla's The Godfather, and is described as 'Hogarth in motion, Peter Greenaway on stage', ${ }^{18}$ while Presely Chweneyagae notes the influence of films like Magnolia and Silence of the Lambs in constructing his vision. However, despite this wide-ranging sweep of cultural residue, the play fixes its gaze inwards on a particular but anonymous post-apartheid urban black community - worlds away, it seems, from that of 'Mandela, Mbeki and whites'. ${ }^{19}$ This underscores the notion that much as things change, they remain the same - the new apartheid of poverty is turned in on itself, and festering, if not flourishing. It is a starkly bleak vision, yet its energy of conception and execution as well as its intertextual play contradict that very starkness through a contrapuntal and muchneeded aesthetic shock-tactic, not unlike the experimental aesthetics associated with the European avant-garde movement, especially Antonin Artaud's Theatre of Cruelty, which sought to shift consciousness by these very shock aesthetics. 
This discussion began by identifying intertextuality as one aspect characterizing a putative post-transitional aesthetics. Drawing on Kristeva's notion of intertextuality as the transposition of an element of one signifying system to another, the presence of one text in another, West-Pavlov notes that for the critical reader this becomes an important instrument of theoretical analysis, while for writers it can be a significant act of 'cultural intervention' - not just of debt, but 'of disturbance and conflict' (51). Intertextuality functions both diachronically and synchronically, and this is how works like Grootboom's set up a dialectic between the immediate, viscerally presented local South African environment, while also locating it within the wider world - not to dilute its here and nowness, but to deepen and problematize the spectator's responses, and to see the local in a way we are not yet used to.

However, instead of simply responding to intertextuality within the work, this needs to be broadened to a reading practice that is relational, extended across geography and time in order to establish conversations between texts that do not necessarily speak to each other -might even be unaware of one another. Establishing this conversation between texts then is also integral to a post-transitional aesthetic which requires openended, but not uncritical, responsiveness, and indeed, response-ability.

Some questions remain: how does one distinguish between a post-transitional aesthetic, and simply 'antics', gratuitous special-effects or new-fangledness in structures of address? This can be tricky to assess, but perhaps the best strategy is to look for internal integrity and coherence, even in apparent chaos, as translated into an aesthetic that while experimental and challenging still allows engagement with our lived experience (including, as Oliver reminds us, subconscious fears and desires). But then, what is the difference between the kind of aesthetics of transformation that have been in evidence from the early 1990 s and even before, and post- transitional aesthetics, particularly given the remarks about the continuum of aesthetic paradigms noted earlier? Another difficult question - and one that again requires openmindedness in assessing - is how the post-transitional aesthetic is not just one we are 'unused to'. Instead, post- transitional aesthetics can be identified in the structures of address and intertextual interventions which speak to the ways of being and of becoming that are called forth by these times. Times of pretence and play, violent and violating paradoxes, of life lived in the details, of paralyzing pasts and occasionally imagined futures. 


\section{NOTES}

1. For instance, in his introduction to the special issue of Current Writing focusing on South African literature 'Beyond 2000' Michael Chapman maps trends in recent commentaries on South African literary production (1-23), while Leon de Kock urges that we need new maps to track the current terrain, and that the time might be right 'to return, provisionally, to a descriptive-evaluative exercise' (116).

2. In his discussion of the terminology to describe the 'second transition' Tim Trengove-Jones rejects the term 'post-apartheid ' to describe the post-election period, and prefers the 'after-life of apartheid'; however, this assumes the overwhelming dead hand of the past in a way that is also problematic(94-108).

3. Although the reference to Oedipus occurred during the 2005 Grahamstown premiere, it is absent from the script published in 2006, based on the run at the Market Theatre. Nevertheless, as I shall show, this reference is not gratuitous and is in keeping with Grootboom's revisionings of classic texts like Sophocles' Electra.

4. According to Kendall Walton, 'what aesthetic features a work seems to have, what aesthetic effect it has on us, how it strikes one aesthetically often depends (in part) on which of its features are standard, which variable, and which contrastandard/or us' (144; my emphasis). Simply put, standard refers to the normally 'perceptually distinguishable' (144), while contra-standard refers to the absence of a standard feature with respect to that category - that is, a feature whose presence tends to disqualify works as members of the category (145).

5. $\quad$ For a fuller discussion of the application of the terms 'utopian' and 'grounded' aesthetics, see Flockemann (2001).

6. See De Kock (2008), Chapman (2009), Nuttall (2009), Hofmeyr (2007), Samuelson (2007) and Titlestad (2004).

7. $\quad$ See Walton (2004), Carroll (1996), and Anderson and Dean (1998).

8. As Sanders notes, imaginative literature is a useful vehicle for representing the complexity of complicity because the act of invention enables ways of articulating complicity by finding a substitute 'in the literary, in the possibilities of alterity offered by its structures of address' (his emphasis 97).

9. Grootboom began his career as a scriptwriter for film and television, and both he and Chweneyagae read widely to prepare their script; the intertextual references will be discussed in more detail later. Recent works directed by Grootboom are Cards (2004/6) and Foreplay (2009).

10. According to Brownlee, Marlene Van Niekerk's Agaat is exemplary for these qualities (in conversation with Michie!Heyns, LitNet, 8 Sept 2006). Further, in an interview with Tom Eaton, Brownlee observes that the shadow of the Big Three Coetzee, Brink and Gordimer - hovers over much of the 'dark introspective fiction that is being produced recently' (Eaton, Litnet, 6 Sept, 2005). On the other hand, Andries du Toit, a cultural commentator, DJ and academic who spawned a slew of responses to his lyrical review of District 9 in his much visited blog, claims, 'I would like to live in a society that acknowledges racial antagonism everywhere, and where we value a text because of the complexity of its engagement with the difficult and loaded topics. I much prefer D9, and Borat, and Spike Lee, and that Black Consciousness Man skit they have over in the UK than carefully inoffensive texts that take fewer risks to make you think' http://asubtleknife .wordpress.com/2009 /09/04/sceinecfiction-in-the-ghetto-loving-the-alien. Accessed on 22 September 09 
11. Titlestad (2007), however, cautions that market-driven forces within the publishing industry could have the potential for 'prefiguring our literary history'. Commenting on his experience as a judge for literary awards, Titlestad observes that some recent 'slice of life' works appear to have been 'rushed through' the publishing process.

12. Cynthia Ward (1990) comments on the way 'living speech' (unlike literary utterance) occurs in various and often contradictory positions, indicative of the presence and possibility of 'multiple and often contradictory stories . . . none being allowed to have precedence over the others without being marked as overtly coercive' (87).

13. Apart from direct references to Toni Morrison's Playing in the Dark, the opening section of the novel which describe Marion's nightmares invite echoes of Paule Marshall 's Praisesong for a Widow.

14. Given that this is such a crucial moment in the text, it is surprising that it does not feature in Maria Olaussen's discussion of complicity in the novel ('Generation and Complicity in Zoe Wicomb's Playing in the Light'. Social Dynamics Vol 35.1,2009: 149-161.)

15. Spencer lists Kagiso Lesego Molope, Zazah Khuzwayo, Zukiswa Wanner, Pamphila Hlapa, Maxine Case, Angela Makbolwa, Angelina Sithole and Futhi Ntshingilala (67).

16. For instance, Nuttall compares Ndumiso Ngcobo's irreverently comic and ironic representation of 'coconuttiness' in his Some of My Best Friends Are White: Subversive Thoughts From an Urban Zulu Warrior (2007) with a more 'literary' approach in Fred Khumalo s Seven Steps to Heaven (2007). In Khumalo's text the coconut is used as an 'initial touchstone 'only to recede in its usefulness as the writer explores a more complex, unpredictable unravelling of writerly and racial territory' (100). Nuttall claims that 'the idea of the coconut represents a first wave in the negotiation of inter- and cross-racial splits and contradictions, within blackness as it has been lived and interpreted so far' (101).

17. This technique is reminiscent of Peter Hayes's 1994 adaptation of Tim Miller's My Queer Body in which a naked Hayes performed being white, male, gay and South African by co-opting some of the theatrical strategies associated with protest theatre.)

18. See Press release for Traverse Theatre, http://74.125.95. 132/search?q=cache:K96RxjmWJB8J:www.traverse .co.uk/show-det. Accessed on 14 September 2009.

19. In response to the charge that their work entrenches negative stereotypes of black South African life, Presely Chweneyagae insists that their work is based on 'real life, but it doesn't define our country. It's just a story we created' (Jones 2006). See anonymous Preview http:/174125.95.132/search?cache:IrBC JCrT5gJ:www.stratfordeast.com/whatson. Accessed on 14 September 2009. 


\section{WORKS CITED}

Anderson, James C. and Jeffrey T. Dean. 'Moderate Autonomism '. British Journal of Aesthetics 38(2), 1998: 150-166.

Arenscbield, Laura. 'Writer: Niq Mhlongo'. An African Interview Series. 8 May 2008.

http://74.125.95.132/search?q=cache:H2vbp9Ale4J:interviews.amagazine.org/\%3

Fp. Accessed on 14 September 2009.

Ashton, Paul et al. 'The Fatherless Sons of Violence'. Cape Argus 23 June 2008: 15.

Barthes, Roland. Image Music Text. Paris: Fontana, 1977.

Carroll, Noel. 'Moderate Moralism'. British Journal of Aesthetics 36(3), 1996:223-238.

Chapman, Michael. 'Introduction: Conjectures on South African Literature'. Current

Writing 21(1\&2), 2009: 1-23.

Corrigall, Mary. 'The Iconoclast'. The Sunday Independent (Sunday Life supplement)

24 January 2010: 26.

-. 'The Great Black Hope'. The Sunday Independent 9 August 2009: 25-26.

De Kock, Leon. 'A History of Restlessness: And Now for the Rest'. English Studies in Africa 51(1), 2008: 109-122.

Eagleton, Terry. TheIdeology of the Aesthetic.London: Blackwell, 1990.

Eaton, Tom. 'Russell Brownlee Takes Us inside Garden of the Plagues'. LitNet 6 September 2005. http:/174.124.95.132/search?q=cache:6tyKoJpMOq YJ :www.oulit.co.za/nosecret/rus . Accessed on 20 September 2009.

Flockemann, Miki. 'The Aesthetics of Transformation: Reading Strategies for South African Theatre'. South African Theatre Journal 15(1\&2), 2001: 25-39.

Frenkel, Ronit. 'Literary Cartographies: A Post-Transitional Palimpsest'. Unpublished paper. Post- Transitional Literary Studies Symposium, University of Johannesburg, 1October 2009.

Gilroy, Paul. The Black Atlantic: Modernity and Double Consciousness. Cambridge: Harvard University Press, 1994.

Gobodo-Madikezela, Pumla. 'Economic Injustice Takes Us to the Precipice: Crisis Calls for Leaders with Moral Courage'. Cape Times 13 June 2008: 9.

Goodman, Lizbeth. Contemporary Feminist Theatres: To Each Her Own. London and New York: Routledge, 1993.

Grootboom, Mpumelelo Paul \& Presley Chweneyagae. Relativity: "Township Stories". Johannesburg: Dung Beetle Dramas, 2006

Hassim, Shireen, Tawana Kupe and Eric Worby. (Eds.). Go Home or Die Here: Violence, Xenophobia and the Reinvention of Difference. Johannesburg: Witwatersrand University Press, 2009.

Heyns, Michie!. 'Michie! Heyns in Conversation with Russell Brownlee'. LitNet 8 September 2006.

http://74.124.95.132/search?q=cache:FFOiAGcnLREJ:www.linet.co.za /cgibin/giga. Accessed on 19 September 2009.

Hofmeyr, Isabel. 'The Black Atlantic Meets the Indian Ocean: Forging New Paradigms of Transnationalism for the Global South Literary and Cultural Perspectives '. Social Dynamics: Oceanic Worlds/Bordered Worlds (ed. Meg Samuelson and Shaun Viljoen) 33(2), 2007: 3-32.

Isaacson, Maureen. 'An Initiate Claiming His Space as a Man'. The Sunday Independent 28 June 2009 (edition 1). http://www.Sundavindependent.co.z 
a/general/print-article.php?articleld $=505623$. Accessed on 22 December 2009.

- - - . Dog Eat Dog world of the township is fast-paced enough to be theatre. The Sunday Independent. July 062008.

http://www.Sundayinmdependentt.co.za/index.php?farticleID=4490973 . Accessed 13 April 2010.

Jacobs, J.U. 'Playing in the Dark I Playing in the Light: Coloured Identity in the Novels of Zoe Wicomb'. Current Writing 2O(1), 2008:1-15.

Jones, Alice. 'A Bleak Vision of South Africa Hits the Stage'. The Independent on Sunday 22 August 2009. http://www.independent.co. uk/artsentertainment/theatre -dance/features/a-bleak-visio. Accessed on 20 September 2009.

Matlwa, Kopano. Coconut. Aukland Park, Johannesburg: Jacana Media Pty Ltd., 2007. Mgqolozana, Thando. A Man WhoIs Not A Man. Scottsville: University of KwaZuluNatal Press, 2009. Mhlonho, Niq. Dog Eat Dog. Cape Town: Kwela Books, 2004.

Meyering, Sharon. 'Once bitten...Interview with Niq Mhlongo'. LitNet 24 June 2004. http://74.125.95.132/search?q=cache:AChDBpjxDI8J:www.oulitnet.co.za/ricoche t/ni. Accessed on 14 September 2009.

Nuttall, Sarah. Entanglements: Literary and Cultural Reflections on Post-Apartheid. Johannesburg: Witwatersrand University Press, 2009.

Olaussen, Maria. 'Generation and Complicity in Zoe Wicomb's Playing in the Light'. Social Dynamics 35(1), 2009: 149-161.

Oliver, Kelly. 'Witnessing and Testimony'. Parallax 20(1), 2004: 79-88.

Phewa, Asansa. A Face Like Mine. Unpublished Play Script. Grahamstown Festival, 2009.

Samuelson, Meg. Remembering the Nation, Dismembering Women? Stories of the South African Transition. Pietermaritzburg: UKZN Press, 2007.

Sanders, Mark. Complicities: The Intellectual and Apartheid. Durham and London: Duke University Press, 2002.

Spencer, Lynda. 'Young, Black and Female in Post-Apartheid South Africa: Identity Politics in Kopano Matlwa's Coconut. Scrutiny2 14(1), 2009: 66-78.

Titlestad, Michael. 'The pitfalls of the literary debut'. Sunday Times 25 March 2007. http://www.shaunjohnson.co.za/articles two.html. Accessed on 29 September 2009. Trengove-Jones, Tim. 'Gay Times: Reading Literature in English in South Africa Today'. English Studies in Africa. 51(1), 2008: 94-108.

Umez, Uche Peter. 'Bubo on My Groin'. Eclectica Magazine October I November 2008.

http://74.125.95.132/search?q=cache:H5hLB53YASIJ:www.eclectica.org/v12n4/u me. Accessed on 14 September 2009.

Walton, Kendall. 'Categories of Art'. Aesthetics and the Philosophy of Art. Ed. Peter Lamargue and Stein Haugom Olsen. Oxford: Blackwell, 2004. 142-157.

Ward, C. 'What They Told Emecheta: Oral Subjectivity and the Joys of "Otherhood"'. PMLA 105(1), 1990: 83-97.

West-Pavlov, Russell. '"Daft Questions': Xenophobia, Teaching, and Social Semiosis in Caribbean- British Fiction: Using Intertextuality and Narratology to Analyze a 
Text by David Dabydeen' . Embracing the Other. New Yorl<IAmsterdam: Rodopi Press, 2008. [49-60?]

Wicomb, Zoe. Playing in the Light. Cape Town: Umuzi, 2006.

Willis, Paul. Common Culture. Buckingham: Open University Press, 1990. 